\title{
Target Screening of Hydroxylated and Nitrated Polycyclic Aromatic Hydrocarbons in Surface Water Using Orbitrap High-Resolution Mass Spectrometry in a Lake in Hebei, China
}

\author{
Zheyuan Shi ${ }^{1}\left(\mathbb{D}\right.$, Zhu Rao ${ }^{1,2, *} \mathbb{C}$, Jun Zhao ${ }^{3}$, Ming Liang ${ }^{4}$, Tao Zhu ${ }^{1}$, Yuan Wang ${ }^{5}$ and Hamidreza Arandiyan ${ }^{6}$ \\ 1 National Research Center for Geoanalysis, Chinese Academy of Geological Science, Beijing 100037, China; \\ disco_good@163.com (Z.S.); zhutao_6@163.com (T.Z.) \\ 2 Key Laboratory of Ecological Geochemistry, Ministry of Natural Resources, Beijing 100037, China \\ 3 Xi'an Geological Survey Center, China Geological Survey, Xi'an 710054, China; zhaojun1981@163.com \\ 4 School of Geoscience and Surveying Engineering, University of Mining and Technology, \\ Beijing 100083, China; mingliang0918@163.com \\ 5 School of Chemistry, The University of New South Wales, Sydney, NSW 2052, Australia; \\ yuan.wang@rmit.edu.au \\ 6 Laboratory of Advanced Catalysis for Sustainability, School of Chemistry, University of Sydney, \\ Sydney, NSW 2006, Australia; hamid.arandiyan@sydney.edu.au \\ * Correspondence: raozhu@126.com
}

\section{check for} updates

Citation: Shi, Z.; Rao, Z.; Zhao, J.; Liang, M.; Zhu, T.; Wang, Y.; Arandiyan, H. Target Screening of Hydroxylated and Nitrated Polycyclic Aromatic Hydrocarbons in Surface Water Using Orbitrap High-Resolution Mass Spectrometry in a Lake in Hebei, China. Separations 2021, 8, 247. https://doi.org/ 10.3390 /separations 8120247

Academic Editor: Fabio Gosetti

Received: 24 October 2021

Accepted: 30 November 2021

Published: 16 December 2021

Publisher's Note: MDPI stays neutral with regard to jurisdictional claims in published maps and institutional affiliations.

Copyright: (c) 2021 by the authors. Licensee MDPI, Basel, Switzerland. This article is an open access article distributed under the terms and conditions of the Creative Commons Attribution (CC BY) license (https:// creativecommons.org/licenses/by/ $4.0 /)$.

\begin{abstract}
Polycyclic aromatic hydrocarbon (PAH) derivatives are mutagenic, carcinogenic, teratogenic and bioaccumulative pollutants. Investigations on hydroxylated PAHs (OH-PAHs) and Nitrated PAHs (NPAHs) in surface water are not enough. In this study, optimization and validation of an analytical method targeting nine kinds of OH-PAHs and one kind of nitrated PAH in environmental water samples are presented. The method was validated for linearity, limits of detection and quantification and recovery using spiked matrix. The linear range of most target compounds was 0.1-200 ng. $\mathrm{mL}^{-1}$. However, the linear range of 1-hydroxy pyrene and 3-hydroxy benzo[a]pyrene started at $1 \mathrm{ng} \cdot \mathrm{mL}^{-1}$ and the linear range of 1-hydroxy phenanthrene and 9-hydroxy benzo[a]pyrene could not reach $200 \mathrm{ng} \cdot \mathrm{mL}^{-1}$. All the correlation coefficients $\left(\mathrm{r}^{2}\right)$ were over 0.997 . The instrumental limits of detection (LOD) and method detection limits (MDL) ranged from 0.01 to $0.67 \mathrm{ng} \cdot \mathrm{mL}^{-1}$ and 1.11 to $2.26 \mathrm{ng} \cdot \mathrm{L}^{-1}$, respectively. With this method, a lake in Hebei province, China, were screened. Three kinds of target compounds were detected. The average concentration was around $2.5 \mathrm{ng} \cdot \mathrm{L}^{-1}$, while the highest concentration reached $286.54 \mathrm{ng} \cdot \mathrm{L}^{-1}$.
\end{abstract}

Keywords: OH-PAH; NPAH; Orbitrap-HRMS; HPLC-HRMS; surface water

\section{Introduction}

Polycyclic aromatic hydrocarbons (PAHs) are mutagenic, carcinogenic, teratogenic and bioaccumulative, and some PAH derivatives are even more toxic [1-7]. Therefore, they are listed as hazardous substances, toxic chemicals and priority pollutants by the United States Environmental Protection Agency (EPA) [8,9]. PAHs and their oxygenated and nitrated derivatives (OPAHs and NPAHs) have been extensively studied, while the hydroxylated derivatives (OH-PAH) have not been sufficiently studied [10]. The major source of $\mathrm{OH}-$ PAHs in the air is the incomplete combustion of coal and biomass [11,12]. Another essential source is the microbiological and photochemical degradation of PAHs [13]. OH-PAHs are polar compounds, indicating that their solubility in water is higher than their parent PAHs. Due to its high sensitivity, high resolving power and accurate mass measurements, the Orbitrap high-resolution Mass Spectrometry (Orbitrap-HRMS) combined with high performance liquid chromatogram (HPLC) has been successfully used in screening PAHs and its derivatives. For example, Avagyan and Westerholm reported a screening method of OH-PAHs in air particulates using LC-Orbitrap-HRMS [14]. Although OH-PAHs have 
been detected in various aqueous matrixes [15-17], investigations on these compounds in surface water are not enough. Especially in lakes and small rivers in the rural area of China.

In this work, we present the optimization of a screening method targeting nine representative kinds of $\mathrm{OH}-\mathrm{PAHs}$ including two pairs of isomers and one NPAH in surface water using HPLC combined with Orbitrap-HRMS. Then, this method was validated in linearity, limits of detection, quantification and matrix effects. With full validation, this method was used in the screening of a shallow lake named Baiyangdian in Hebei province, China. This provided an example for further and wider investigation on PAH derivatives in surface water.

\section{Materials and Methods}

\subsection{Chemicals}

Analytical grade standards including 2-Phenyl phenol, 1-naphthol, 2-naphthol, 1-hydroxy pyrene, 7,8-benzoquinoline and 6-hydroxy chrysene were purchased from AccuStandard (New Haven, CT, USA). 1-hydroxy phenanthrene, 3-hydroxy fluorene, 3-hydroxy benzo[a]pyrene and 9-hydroxy benzo[a]pyrene were purchased from Toronto Research Chemicals Incorporation (Toronto, Ontrario, Canada). Detailed information on these reference standards are shown in Table 1. Acetonitrile and methanol, both HPLC grade, were purchased from Merck (Darmstadt, Hessen, Germany). Ultrapure water was produced by a Milli-Q system (Millipore, Billerica, MA, USA).

All standards were purchased as solutions of $100 \mathrm{mg} \cdot \mathrm{L}^{-1}$ in methanol. $100 \mu \mathrm{L}$ of each standard solution was mixed as stock solution and kept in a freezer under $-18 \sim-20{ }^{\circ} \mathrm{C}$. $100 \mu \mathrm{L}$ of stock was diluted with methanol to $1 \mathrm{~mL}$ as mixed standard for later use.

\subsection{Study Area and Sampling}

The study area was the biggest shallow lake in Hebei province, China, known as Baiyangdian. It is the main water source of residents in the area, as well as a representative of surface water environment in the rural area of north China. During June and July of 2018, forty samples were obtained from the lake and from upstream. Each sample were directly collected with a $1 \mathrm{~L}$ dark glass bottle along with two duplicates. All samples and duplicates were then stored at $0 \sim 4{ }^{\circ} \mathrm{C}$ using ice bags and transported back to our laboratory for extraction within 7 days.

\subsection{Extraction}

C18 solid phase extraction (SPE) (6 cc, 500 mg, Agela Technologies, Shanghai, China) was used to extract all environmental samples and spiked blank samples. SPE cartridges were conditioned with $5 \mathrm{~mL}$ methanol and then $5 \mathrm{~mL}$ water. After being conditioned, SPE cartridges were placed on a glass tank, where negative pressure was applied. Then, $1 \mathrm{~L}$ of each sample were added. All samples were not filtered and it took 20 to $25 \mathrm{~min}$ to load each cartridge. However, some samples did not go as fast as others. The slowest sample took about $45 \mathrm{~min}$ to load. The cartridges were then washed with $5 \mathrm{~mL}$ water, and the analytes were eluted with $4 \mathrm{~mL}$ methanol. The eluted fractions were evaporated to $500 \mu \mathrm{L}$ and filtered by $0.22 \mu \mathrm{m}$ Nylon filters.

\subsection{LC and MS Conditions}

The analyses were performed on an Ultimate 3000 Rapid Separation Liquid Chromatography (RSLC) system (Thermo Scientific Dionex, Germering, Bayern, Germany) coupled to a Q Exactive Plus Hybrid Quadrupole-Orbitrap High Resolution Mass Spectrometer (HR-Orbitrap-MS) with heated electrospray ionization (HESI) ion source (Thermo Scientific, Bremen, Germany). 
Table 1. Detailed information on target compounds.

\begin{tabular}{|c|c|c|c|c|c|c|}
\hline Name & Abbr. & Formula & Structure & CAS-No. & $\begin{array}{c}\text { Target } \\
\text { Ion }(\mathrm{m} / \mathrm{z})\end{array}$ & $\begin{array}{c}\text { Ion } \\
\text { Polarity }\end{array}$ \\
\hline 1-naphthol & 1-OH-Nap & $\mathrm{C}_{10} \mathrm{H}_{8} \mathrm{O}$ & & $90-15-3$ & 143.05024 & Negative \\
\hline 2-naphthol & 2-OH-Nap & $\mathrm{C}_{10} \mathrm{H}_{8} \mathrm{O}$ & & $135-19-3$ & 143.05024 & Negative \\
\hline $\begin{array}{l}\text { 2-phenyl phenol } \\
\text { (2-hydroxy biphenyl) }\end{array}$ & 2-OH-Bip & $\mathrm{C}_{12} \mathrm{H}_{10} \mathrm{O}$ & & $90-43-7$ & 169.06589 & Negative \\
\hline 3-hydroxy fluorene & 3-OH-Flu & $\mathrm{C}_{13} \mathrm{H}_{10} \mathrm{O}$ & & $6344-67-8$ & 181.06589 & Negative \\
\hline 7,8-benzoquinoline & 7,8-BQu & $\mathrm{C}_{13} \mathrm{H}_{9} \mathrm{~N}$ & & $230-27-3$ & 180.08078 & Positive \\
\hline 1-hydroxy pyrene & 1-OH-Pyr & $\mathrm{C}_{16} \mathrm{H}_{10} \mathrm{O}$ & & $5315-79-7$ & 193.06589 & Negative \\
\hline $\begin{array}{l}\text { 1-hydroxy } \\
\text { phenanthrene }\end{array}$ & 1-OH-Phe & $\mathrm{C}_{14} \mathrm{H}_{10} \mathrm{O}$ & & $2433-56-9$ & 217.06589 & Negative \\
\hline 6-hydroxy chrysene & 6-OH-Chr & $\mathrm{C}_{18} \mathrm{H}_{12} \mathrm{O}$ & & $37515-51-8$ & 243.08154 & Negative \\
\hline $\begin{array}{c}\text { 9-hydroxy } \\
\text { benzo[a]pyrene }\end{array}$ & 9-OH-BaP & $\mathrm{C}_{20} \mathrm{H}_{12} \mathrm{O}$ & & 17573-21-6 & 267.08154 & Negative \\
\hline $\begin{array}{c}\text { 3-hydroxy } \\
\text { benzo[a]pyrene }\end{array}$ & 3-OH-BaP & $\mathrm{C}_{20} \mathrm{H}_{12} \mathrm{O}$ & & $133345-21-6$ & 267.08154 & Negative \\
\hline
\end{tabular}

A Kinetex F5 column (2.1\% $100 \mathrm{~mm}$ length and diameter, $2.6 \mu \mathrm{m}$ particle size, Phenomenex, Torrance, CA, USA) was used for the separation. The column temperature was kept at $30^{\circ} \mathrm{C}$, and the injection volume was $20 \mu \mathrm{L}$. Mobile phase A was ultrapure water, and mobile phase $B$ was methanol, and the flow rate was set to $0.25 \mathrm{~mL} \cdot \mathrm{min}^{-1}$, for a total of $20 \mathrm{~min}$. The percentage of mobile phase B was $50 \%$ for the first $2 \mathrm{~min}$, then ramped to $80 \%$ in the next $13 \mathrm{~min}$, and stayed $80 \%$ for $3 \mathrm{~min}$, then ramped back down to $50 \%$ in $0.1 \mathrm{~min}$ and held for $1.9 \mathrm{~min}$.

Most $\mathrm{OH}-\mathrm{PAHs}$ rapidly lose $\mathrm{H}^{+}$in the HESI ion source and become negatively charged ions. However, NPAH such as 7,8-BQu attracts $\mathrm{H}^{+}$and gains positive charge in the HESI ion source. To analyze all compounds of both polarities without affecting efficiency, 
the MS acquisition was performed in negative ionization mode and positive ionization mode simultaneously.

A T-SIM scan with two scan groups was established. The $m / z$ and polarity of each target compounds were shown in Table 1 . the spray voltage was set to $-3.2 \mathrm{kV}$ and $+3.5 \mathrm{kV}$. Sheath gas flow rate was 55 arbitrary units (a.u.), sweep gas flow rate was 0 a.u. S-lens radio frequency level was 50 a.u., the capillary temperature was $360^{\circ} \mathrm{C}$, and auxiliary (AUX) gas heater temperature was $400{ }^{\circ} \mathrm{C}$. The mass resolution was 70,000 $(\mathrm{m} / z 200)$, automatic gain control (AGC) target was set to 1e6, maximum injection time was $100 \mathrm{~ms}$ and isolation window was $2.0 \mathrm{~m} / \mathrm{z}$.

\section{Results and Discussion}

\subsection{Extraction Optimization}

\subsubsection{Choosing SPE Columns}

To compare the efficiency of extraction on three kinds of commonly used SPE sorbent, HLB, PEP and C18, seven blank matrix samples spiked with mix standard were extracted using each SPE column and then analyzed. The analytical concentration compared to the spiked concentration was calculated as recovery for each analyte. The recoveries on C18 SPE columns were between $60-100 \%$, except for $3-\mathrm{OH}-\mathrm{BaP}(54.9 \%)$. However, only six analytes on HLB SPE columns had recoveries that reached $60 \%$, while recoveries of five analytes on PEP SPE columns achieved the same level. Therefore, C18 SPE column was the final choice.

\subsubsection{Choosing Elute Solvent}

In order to determine which and how much Elute solvent to use, eight sets of analyses were performed using different amounts of methanol or acetonitrile as eluting solvent. The recoveries of each group were calculated and shown in Figure 1. Most compounds reached the highest recovery eluted at $4 \mathrm{~mL}$ methanol.

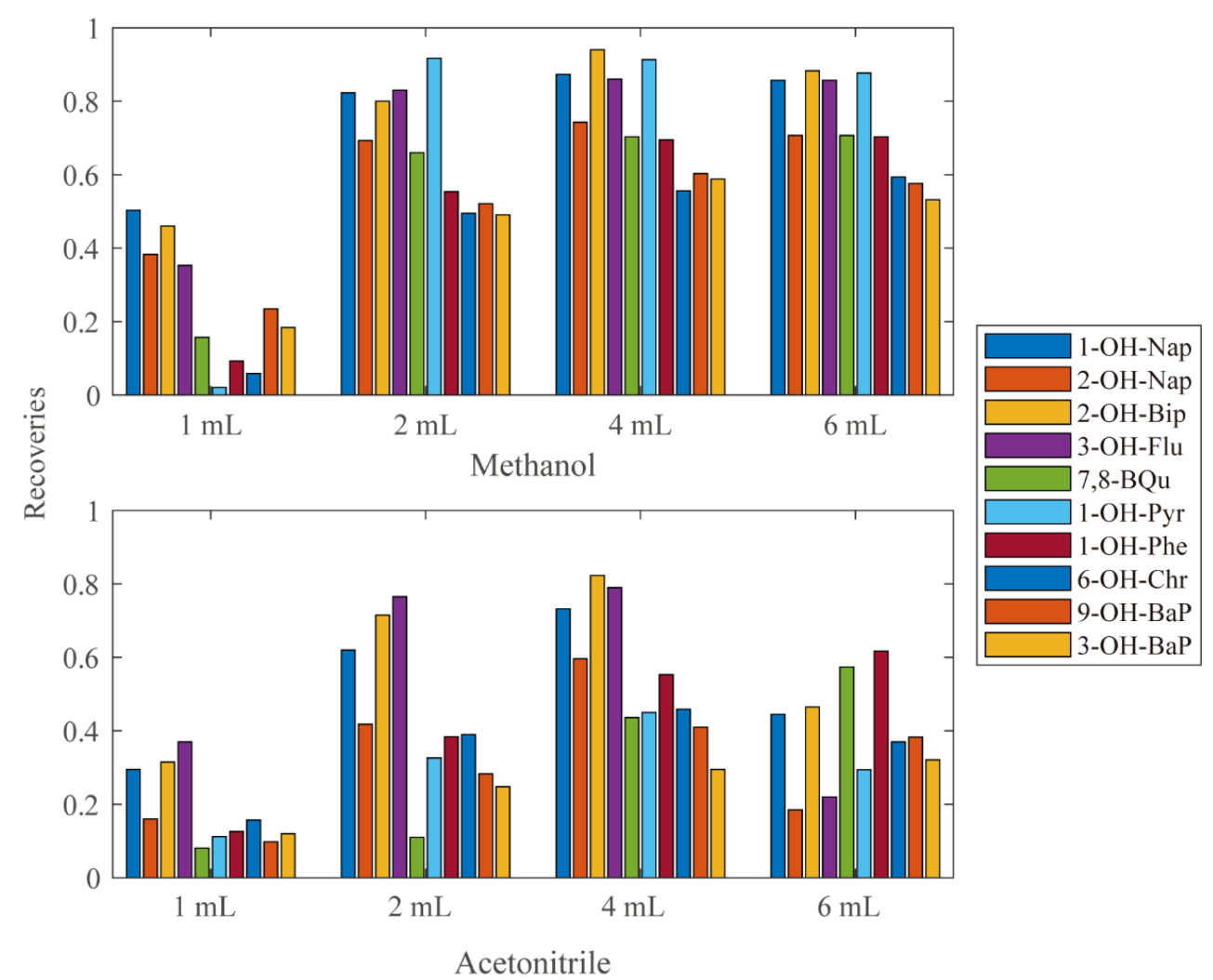

Figure 1. The recoveries using different kinds and amount of elute solvents. 


\subsection{LC Optimizing}

Isomers such as $1-\mathrm{OH}-\mathrm{Nap} / 2-\mathrm{OH}-\mathrm{Nap}$ and $9-\mathrm{OH}-\mathrm{BaP} / 3-\mathrm{OH}-\mathrm{BaP}$ are unable to be identified by the target $\mathrm{m} / \mathrm{z}$. Therefore, LC optimizing is critical for isolating and quantifying those isomers.

\subsubsection{Choosing of Columns}

At first, a waters ACQUITY UPLC BEH C18 $(2.1 \times 100 \mathrm{~mm}, 1.7 \mu \mathrm{m})$ column was used for separation. The gradient profile was $50 \%$ of phase B in the first $2.5 \mathrm{~min}$, then gradually increased and reached $80 \%$ at the $18.75 \mathrm{~min}$. Then, kept for $3.75 \mathrm{~min}$, then ramped back to $50 \%$ in $0.1 \mathrm{~min}$ and stayed $50 \%$ in the last $2.4 \mathrm{~min}$. Other conditions were the same as Section 2, Materials and Methods (line 83-89). However, the resolution of 1-OH-Nap (retention times $(\mathrm{RT})=5.95)$ and $2-\mathrm{OH}-\mathrm{Nap}(\mathrm{RT}=6.32)$ was 0.617 which was unacceptable. Then, a Phenomenex Kinetex F5 $(2.1 \times 100 \mathrm{~mm}, 2.6 \mu \mathrm{m})$ column were tested for isolating target compounds. The extracted ion chromatograms (EIC) were shown in Figure 2. The resolution of $1-\mathrm{OH}-\mathrm{Nap}(\mathrm{RT}=4.20)$ and $2-\mathrm{OH}-\mathrm{Nap}(\mathrm{RT}=4.86)$ was over 1.5 and the resolution of $9-\mathrm{OH}-\mathrm{BaP}(\mathrm{RT}=17.04)$ and $3-\mathrm{OH}-\mathrm{BaP}(\mathrm{RT}=17.42)$ was 1.438. Both isomer pairs were well separated.

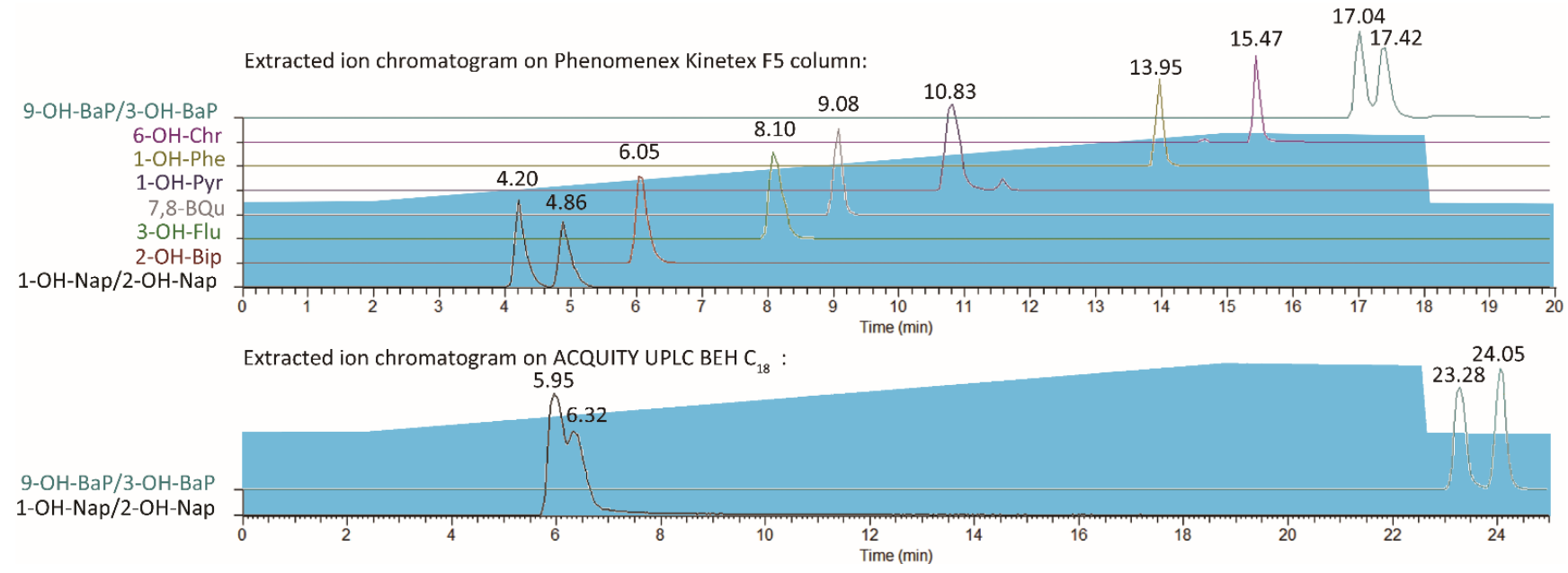

Figure 2. Extracted ion chromatograms on two columns.

\subsubsection{Column Temperature and Mobile Phase Optimizing}

Methanol and acetonitrile are both commonly used mobile phase B in reverse phase chromatography. Both mobile phases were tested under common condition. While using acetonitrile as mobile phase B, the resolution and peak tailing was not as good as using Methanol.

Then, four different gradient profiles as in Table 2. were tested; 9-OH-BaP/3-OH-BaP were not welly separated using gradient profiles 1 and 2 . When using gradient profile 3 , the $\mathrm{RT}$ of $9-\mathrm{OH}-\mathrm{BaP}$ and 3-OH-BaP were over $20 \mathrm{~min}$. Therefore, the efficiency and resolution of profile 4 were the best.

Table 2. Gradient profiles of mobile phase B.

\begin{tabular}{ccccccc}
\hline Time (min): & $\mathbf{0}$ & $\mathbf{2}$ & $\mathbf{1 5}$ & $\mathbf{1 8}$ & $\mathbf{1 8 . 1}$ & $\mathbf{2 0}$ \\
\hline Profile 1 & $40 \%$ & $40 \%$ & $95 \%$ & $95 \%$ & $40 \%$ & $40 \%$ \\
Profile 2 & $50 \%$ & $50 \%$ & $95 \%$ & $95 \%$ & $50 \%$ & $50 \%$ \\
Profile 3 & $50 \%$ & $50 \%$ & $70 \%$ & $70 \%$ & $50 \%$ & $50 \%$ \\
Profile 4 & $50 \%$ & $50 \%$ & $80 \%$ & $80 \%$ & $50 \%$ & $50 \%$ \\
\hline
\end{tabular}


The column temperature and the flow rate of mobile phase are two major factors that determine the resolution, other than the columns. Four chromatographs were obtained with the column temperature at $25{ }^{\circ} \mathrm{C}, 30{ }^{\circ} \mathrm{C}, 35^{\circ} \mathrm{C}$ and $40{ }^{\circ} \mathrm{C}$, respectively, and three more were obtained under mobile phase flow rate at $0.25 \mathrm{~mL} \cdot \mathrm{min}^{-1}, 0.30 \mathrm{~mL} \cdot \mathrm{min}^{-1}$ and $0.35 \mathrm{~mL} \cdot \mathrm{min}^{-1}$. Figure 3 showed the calculated resolution of each isomer pairs. However, since the retention time increases along with the increase in resolution, the efficiency, along with other factors such as the service life period of columns, were taken into consideration in the final choice of temperature and flow rate.

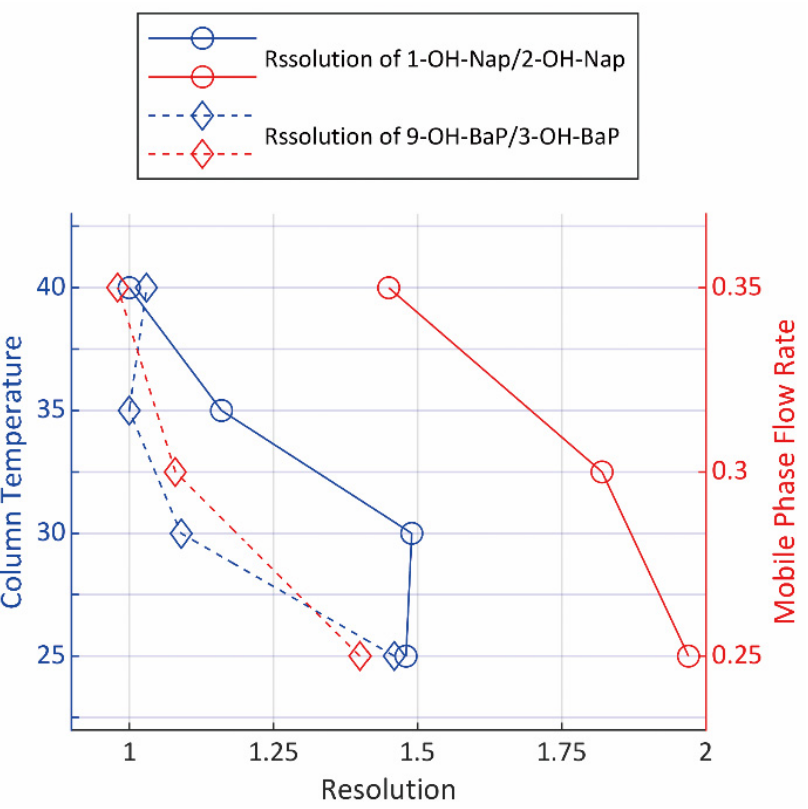

Figure 3. The resolution of isomers under different LC parameters.

\subsection{HESI Source Tuning}

To maximize the efficiency of the HESI source, a targeted tuning was performed. The relative response under different capillary temperature, AUX gas heater temperature, spray voltage and sheath gas flow rate are shown in Figure 4. However, for different compounds, the ionic efficiency reached its peak under different parameters. Thus, the final choice of parameters was a compromise to ensure the response of most analytes were as strong as possible.

\subsection{Calibration and Validation}

The calibration curve ranged from $0.1 \mathrm{ng} \cdot \mathrm{mL}^{-1}$ to $200 \mathrm{ng} \cdot \mathrm{mL}^{-1}$ and at included at least seven calibration points. The instrumental limits of detection (LOD) were calculated from signal to noise ratios $(\mathrm{S} / \mathrm{N})$ of standard solutions using the definition $\mathrm{S} / \mathrm{N}>3$. Instrumental relative standard deviation (RSD $n=7$ ) was calculated by repeatedly analyzing mix standard solution at $5 \mathrm{ng} \cdot \mathrm{mL}^{-1}$ for seven times. Additionally, the method detection limits (MDL) was calculated according to the EPA definition of MDL, which is $t_{(n-1,0.99)} \times$ Standard Deviation. In order to determine the reproducibility of extraction, $1 \mathrm{~L}$ of pure water was spiked with $5 \mu \mathrm{L}, 30 \mu \mathrm{L}$ and $100 \mu \mathrm{L}$ mixed standard solution, respectively and repeated 7 times each. Then, the spiked water was extracted and analyzed. The recovery and RSD of extraction at three concentrations $\left(5 \mathrm{ng} \cdot \mathrm{mL}^{-1}, 30 \mathrm{ng} \cdot \mathrm{mL}^{-1}\right.$ and $\left.100 \mathrm{ng} \cdot \mathrm{mL}^{-1}\right)$ were then calculated. The matrix effects were determined according to the procedure by Avagyan and Westerholm in 2017 [14], which included spiking the matrix extract with mix standard solutions and comparing the response factors to those obtained from pure mixed standard solutions. All detailed information on method calibration and validation is shown in Tables 3 and 4. 


\subsection{Screening Results}

Seven of 10 target compounds did not reach the concentration of MDL in all 40 samples. The concentration of 1-OH-Nap, 2-OH-Nap and 2-OH-Bip were over MDL in 6, 1 and 22 samples, respectively. The maximum concentrations of 1-OH-Nap, 2-OH-Nap and 2-OH-Bip were $286.54 \mathrm{ng} \cdot \mathrm{L}^{-1}, 2.55 \mathrm{ng} \cdot \mathrm{L}^{-1}$ and $73.97 \mathrm{ng} \cdot \mathrm{L}^{-1}$. Since the maximum concentration of 1-OH-Nap was over the linear range, the concentration of this sample was calibrated by a mixed standard solution at the concentration of $300 \mathrm{ng} \cdot \mathrm{L}^{-1}$, additionally, double checked with the duplicate of this sample. The EIC chromatogram of this sample is shown in Figure 5.
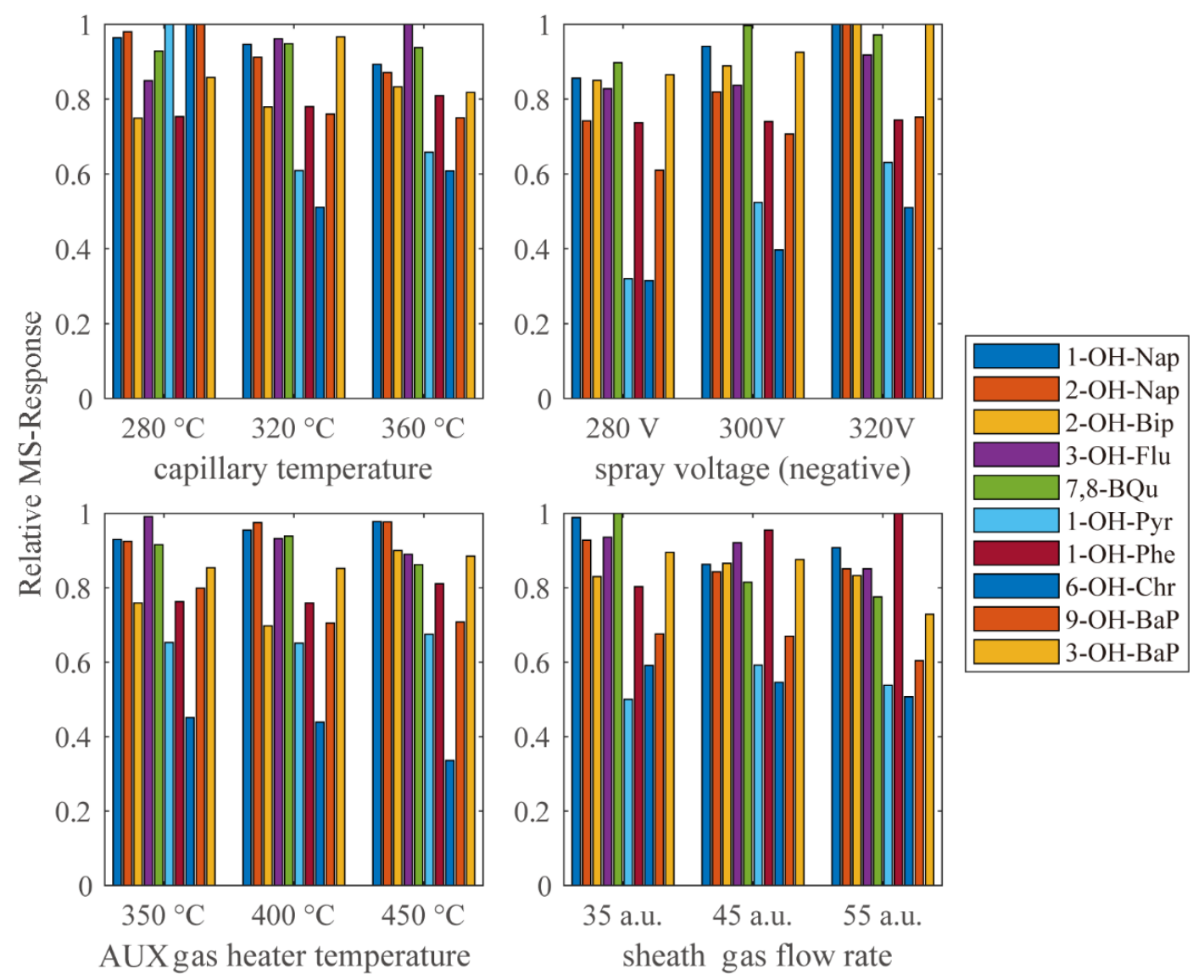

Figure 4. The MS-response relative to the highest response in each group under different HESI parameters.

Table 3. RT, linear range, correlation coefficients $\left(\mathrm{r}^{2}\right)$, LOD, LOQ and instrument RSD $(n=7)$ of each compound.

\begin{tabular}{|c|c|c|c|c|c|c|}
\hline Compound & RT (min) & $\begin{array}{l}\text { Linear Range } \\
\left(\mathrm{ng} \cdot \mathrm{mL}^{-1}\right)\end{array}$ & $\mathbf{r}^{2}$ & $\begin{array}{c}\text { LOD } \\
\left(\mathrm{ng} \cdot \mathrm{mL}^{-1}\right)\end{array}$ & RSD (\%) & $\operatorname{MDL}\left(\operatorname{ng~L~}^{-1}\right)$ \\
\hline 1-OH-Nap & 4.20 & $0.1-200$ & 0.9998 & 0.01 & 1.98 & 1.78 \\
\hline 2-OH-Nap & 4.86 & $0.1-200$ & 0.9998 & 0.01 & 1.65 & 2.05 \\
\hline 2-OH-Bip & 6.05 & $0.1-200$ & 0.9998 & 0.01 & 0.88 & 1.10 \\
\hline 3-OH-Flu & 8.10 & $0.1-200$ & 0.9990 & 0.05 & 2.17 & 1.41 \\
\hline 7,8-BQu & 9.08 & $0.1-200$ & 0.9990 & 0.05 & 1.29 & 1.69 \\
\hline $1-\mathrm{OH}-\mathrm{Pyr}$ & 10.83 & $1-200$ & 0.9978 & 0.28 & 2.54 & 1.73 \\
\hline 1-OH-Phe & 13.95 & $0.1-50$ & 0.9983 & 0.01 & 1.37 & 1.42 \\
\hline 6-OH-Chr & 15.47 & $0.1-100$ & 0.9991 & 0.08 & 1.54 & 1.66 \\
\hline 9-OH-BaP & 17.04 & $0.1-50$ & 0.9980 & 0.25 & 2.44 & 1.53 \\
\hline 3-OH-BaP & 17.42 & $1-100$ & 0.9991 & 0.37 & 3.08 & 2.26 \\
\hline
\end{tabular}


Table 4. RSD ( $n=7)$ and recovery (R) of extraction at different concentrations and matrix effects.

\begin{tabular}{|c|c|c|c|c|c|c|c|}
\hline \multirow{2}{*}{ Compound } & \multicolumn{2}{|c|}{$5 \mathrm{ng} \cdot \mathrm{L}^{-1}$} & \multicolumn{2}{|c|}{$30 \mathrm{ng} \cdot \mathrm{L}^{-1}$} & \multicolumn{2}{|c|}{$100 \mathrm{ng} \cdot \mathrm{L}^{-1}$} & \multirow{2}{*}{ Matrix Effect } \\
\hline & RSD (\%) & R (\%) & RSD (\%) & R (\%) & RSD (\%) & R (\%) & \\
\hline 1-OH-Nap & 6.9 & 91.2 & 4.9 & 89.7 & 8.8 & 85.4 & 97.8 \\
\hline 2-OH-Nap & 8.2 & 79.7 & 6.4 & 76.4 & 6.3 & 74.3 & 99.9 \\
\hline 2-OH-Bip & 4.6 & 96.6 & 5.0 & 98.7 & 7.4 & 90.0 & 95.7 \\
\hline 3-OH-Flu & 4.1 & 86.5 & 4.3 & 81.3 & 5.6 & 80.5 & 93.6 \\
\hline $7,8-\mathrm{BQu}$ & 7.8 & 68.9 & 2.8 & 69.8 & 3.9 & 73.6 & 104.7 \\
\hline 1-OH-Pyr & 6.4 & 85.9 & 10.0 & 86.4 & 4.5 & 86.7 & 95.0 \\
\hline 1-OH-Phe & 5.8 & 77.9 & 5.4 & 70.3 & 6.1 & 78.6 & 113.1 \\
\hline 6-OH-Chr & 10.3 & 51.4 & 7.3 & 54.3 & 9.6 & 59.3 & 106.7 \\
\hline 9-OH-BaP & 9.7 & 50.3 & 10.7 & 59.6 & 7.7 & 63.4 & 105.1 \\
\hline 3-OH-BaP & 14.9 & 45.3 & 12.3 & 49.7 & 7.8 & 54.9 & 93.4 \\
\hline
\end{tabular}

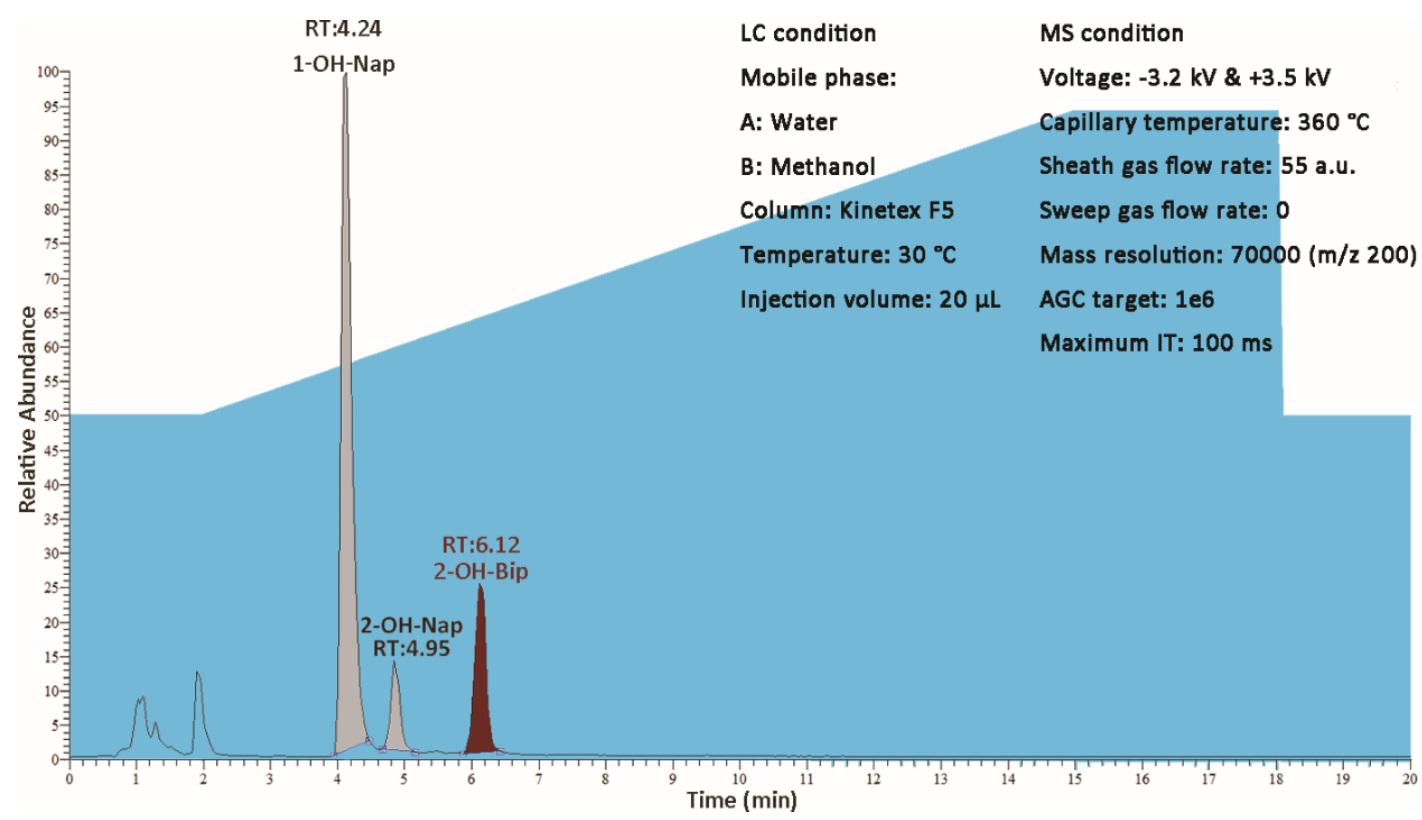

Figure 5. The EIC chromatogram which had the maximum concentration of 1-OH-Nap.

Statistics of compounds with a concentration above MDL are listed in Table 5. The result shows that in nearly half of the samples the concentration of all targets was below MDL. Additionally, the median concentration was around $2.5 \mathrm{ng} \cdot \mathrm{L}^{-1}$, which suggests that the concentration in most of the lake is around $2.5 \mathrm{ng} \cdot \mathrm{L}^{-1}$ or even lower. However, the maximum concentration was much higher, which suggests that the concentration was highly unevenly distributed.

Table 5. Maximum and median concentrations, number, and rate of concentrations above MDL and the sample number with the maximum concentrations.

\begin{tabular}{cccc}
\hline Compounds & 1-OH-Nap & 2-OH-Nap & 2-OH-Bip \\
\hline Number of Concentrations above MDL & 6 & 1 & 22 \\
Rate of Concentrations above MDL $(\%)$ & 15.0 & 2.5 & 55.0 \\
Maximum Concentration $\left(\mathrm{ng} \cdot \mathrm{L}^{-1}\right.$ ) & 286.54 & 2.55 & 73.97 \\
Median Concentration $\left(\mathrm{ng} \cdot \mathrm{L}^{-1}\right.$ ) & 2.32 & 2.55 & 2.88 \\
MDL Concentration $\left(\mathrm{ng} \cdot \mathrm{L}^{-1}\right.$ ) & 1.78 & 2.05 & 1.10 \\
Maximum Concentration Sample & Sample 30 & Sample 30 & Sample 35 \\
\hline
\end{tabular}


To understand the distribution of $\mathrm{OH}-\mathrm{PAHs}$ in the lake, the concentration heat map of 2-OH-Bip, 1-OH-Nap and 2-OH-Nap was shown in Figure 6b-d. Additionally, the relative position of sampling points is shown in Figure 6a. The red square represents the mapping area of the heat maps. Due to the anomalous distribution, the colour scale is exponential. For Figure $6 \mathrm{~b}, \mathrm{c}$, the concentration of most of the yellow area is around $2 \mathrm{ng} \cdot \mathrm{L}^{-1}$ and that of the blue area is below MDL. The red areas suggest the high concentration of $\mathrm{OH}-\mathrm{PAHs}$ only appears in a small area of the lake. The red zone of Figure $6 c, \mathrm{~d}$ is at the same spot, but very different form Figure $6 \mathrm{~b}$, which shows the concentrations of $1-\mathrm{OH}-\mathrm{Nap}$ and 2-OH-Bip reach their peak at sampling point 30 (S30), while the concentration of 2-OH-Bip reaches the peak at sampling point 35 (S35), and a second peak at sampling point 39 (S39).

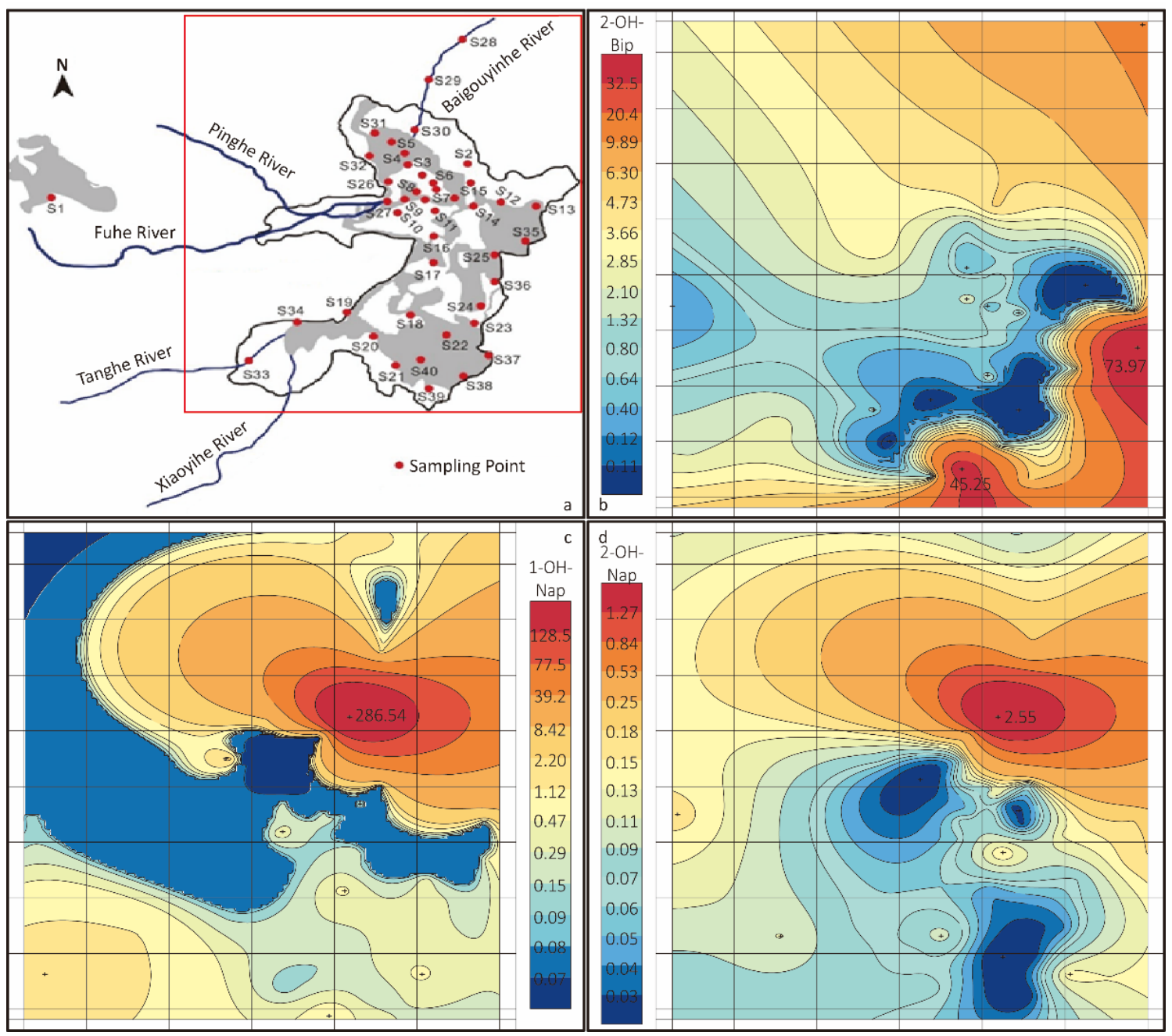

Figure 6. (a) The relative position of sampling points. (b-d) Concentration heat map of 2-OH-Bip, 1-OH-Nap and 2-OH-Nap, respectively.

The high concentration of OH-PAHs appears only in a small area, suggesting that $\mathrm{OH}-\mathrm{PAHs}$ in that area accumulate much faster than it disperses and degrades, which indicates a strong source of $\mathrm{OH}-\mathrm{PAH}$ in the high concentration area. To identify the source, a further investigation is needed concentrated on those red zones. One assumption is the fuel combustion of a yacht dock at the entrance of Baigouyinhe River near S30. 


\section{Conclusions}

The optimization and validation of a target screening method using HPLC-Orbitrap HRMS were presented in this work. The linear range, correlation coefficients, RSD and MLD was sufficiently well for the investigation of environmental samples. The matrix effect was not severe (93-113\%). Although ten targeted compounds were listed, we hope to expand this method to nontarget screening. Internal standard was not used in order to simulate screening unknown compounds.

With this method, a screening of nine OH-PAHs and one NPAH in the lake, Baiyangdian Hebei, China was successfully conducted. The concentration of seven target compounds did not reach MLD in all samples, while the concentrations of other three compounds were around $2.5 \mathrm{ng} \cdot \mathrm{L}^{-1}$ in most of the lake, demonstrating that the overall pollution of $\mathrm{OH}-\mathrm{PAH}$ in this area was not severe. However, an overwhelming high concentration area of 1-OH-Nap at sampling point 30 and two peak concentration areas of 2-OH-Bip were detected. These three areas need to be further investigated to understand the reason of this irregularity.

The screening results testify to the ubiquitous existence of $\mathrm{OH}-\mathrm{PAH}$ in water. Additionally, they suggest the importance of establishing a standard procedure for a nation-wide investigation on surface water.

Author Contributions: Z.S.: formal analysis, validation, visualization, and writing. Z.R.: conceptualization, funding acquisition and supervision. J.Z.: visualization. M.L.: formal analysis, resources. T.Z.: formal analysis and resources. Y.W.: editing. H.A.: editing. All authors have read and agreed to the published version of the manuscript.

Funding: This research was funded by China Geological Survey (DD20190323, DD20189627).

Institutional Review Board Statement: Not applicable.

Informed Consent Statement: Not applicable.

Data Availability Statement: Not applicable.

Conflicts of Interest: The authors declare no conflict of interest. The funders had no role in the design of the study; in the collection, analyses, or interpretation of data; in the writing of the manuscript, or in the decision to publish the results.

\section{References}

1. International Agency for Research on Cancer. Overall evaluations of carcinogenicity: An updating of IARC Monographs volumes 1 to 42. IARC Monogr. Eval. Carcinog. Risks Hum. Suppl. 1987, 7, 1-440.

2. Vandergrift, G.W.; Monaghan, J.; Krogh, E.T.; Gill, C.G. Direct Analysis of Polyaromatic Hydrocarbons in Soil and Aqueous Samples Using Condensed Phase Membrane Introduction Tandem Mass Spectrometry with Low-Energy Liquid Electron Ionization. Anal. Chem. 2019, 91, 1587-1594. [CrossRef]

3. Durant, J.L.; Lafleur, A.L.; Plummer, E.F.; Taghizadeh, K.; Busby, W.F.; Thilly, W.G. Human Lymphoblast Mutagens in Urban Airborne Particles. Environ. Sci. Technol. 1998, 32, 1894-1906. [CrossRef]

4. Hannigan, M.P.; Cass, G.R.; Penman, B.W.; Crespi, C.L.; Lafleur, A.L.; Busby, W.F.; Thilly, W.G.; Simoneit, B.R.T. Bioassay-Directed Chemical Analysis of Los Angeles Airborne Particulate Matter Using a Human Cell Mutagenicity Assay. Environ. Sci. Technol. 1998, 32, 3502-3514. [CrossRef]

5. Schuetzle, D. Sampling of vehicle emissions for chemical analysis and biological testing. Environ. Health Perspect. 1983, 47, 65-80. [CrossRef] [PubMed]

6. Pedersen, D.U.; Durant, J.L.; Penman, B.W.; Crespi, C.L.; Hemond, H.F.; Lafleur, A.L.; Cass, G.R. Human-cell mutagens in respirable airborne particles in the northeastern United States. 1. Mutagenicity of fractionated samples. Environ. Sci. Technol. 2004, 38, 682-689. [CrossRef] [PubMed]

7. Pedersen, D.U.; Durant, J.L.; Taghizadeh, K.; Hemond, H.F.; Lafleur, A.L.; Cass, G.R. Human cell mutagens in respirable airborne particles from the northeastern United States. 2. Quantification of mutagens and other organic compounds. Environ. Sci. Technol. 2005, 39, 9547-9560. [CrossRef] [PubMed]

8. Priority Pollutant List. Available online: https://www.epa.gov/sites/production/files/2015-09/documents/priority-pollutantlist-epa.pdf (accessed on 30 August 2021).

9. List of Lists. Available online: https:/ / www.epa.gov/sites/production/files/2015-03/documents/list_of_lists.pdf (accessed on 30 August 2021). 
10. Zhang, H.-Q.; Rao, Z.; Wang, X.-C.; Xu, D.-D.; Gu, Z.-X.; Qin, K.; Guo, F.; Zhan, N. Determination of Low-ring PAHs and Their Derivatives in Groundwater by GC $\times$ GC-TOF MS. J. Instrum. Anal. 2017, 36, 1197-1202.

11. Simoneit, B.R.; Bi, X.; Oros, D.R.; Medeiros, P.M.; Sheng, G.; Fu, J. Phenols and hydroxy-PAHs (arylphenols) as tracers for coal smoke particulate matter: Source tests and ambient aerosol assessments. Environ. Sci. Technol. 2007, 41, 7294-7302. [CrossRef] [PubMed]

12. Avagyan, R.; Nyström, R.; Lindgren, R.; Boman, C.; Westerholm, R. Particulate hydroxy-PAH emissions from a residential wood $\log$ stove using different fuels and burning conditions. Atmos. Environ. 2016, 140, 1-9. [CrossRef]

13. Pozzoli, L.; Gilardoni, S.; Perrone, M.G.; de Gennaro, G.; de Rienzo, M.; Vione, D. Polycyclic Aromatic Hydrocarbons in the Atmosphere: Monitoring, Sources, Sinks And Fate. I: Monitoring And Sources. Ann. Di Chim. 2004, 94, 17-33. [CrossRef] [PubMed]

14. Avagyan, R.; Westerholm, R. Target and suspect screening of OH-PAHs in air particulates using liquid chromatography-orbitrap high resolution mass spectrometry. Talanta 2017, 165, 702-708. [CrossRef] [PubMed]

15. Hemat, H.; Wittsiepe, J.; Wilhelm, M.; Muller, J.; Goen, T. High levels of 1-hydroxypyrene and hydroxyphenanthrenes in urine of children and adults from Afghanistan. J. Expo. Sci. Environ. Epidemiol. 2012, 22, 46-51. [CrossRef] [PubMed]

16. Guo, Y.; Senthilkumar, K.; Alomirah, H.; Moon, H.B.; Minh, T.B.; Mohd, M.A.; Nakata, H.; Kannan, K. Concentrations and profiles of urinary polycyclic aromatic hydrocarbon metabolites (OH-PAHs) in several Asian countries. Environ. Sci. Technol. 2013, 47, 2932-2938. [CrossRef] [PubMed]

17. Dan, L.; Chun-xiang, H.; Guang-shui, N.; Rui-jing, L.; Yu-hang, G.; Sheng-kai, C. Determination of hydroxylated polycyclic aromatic hydrocarbons in seawater by ultra performance liquid chromatography and mass spectrometry- $\mathrm{C}_{18}$ membrane disk extraction. Chin. J. Anal. Lab. 2018, 37, 884-888. 